\title{
Maize Response to Chemical and Microbial Products on Two Tanzanian Soils
}

\author{
Kiriba Deodatus ${ }^{1,2}$, Thuita Moses ${ }^{3}$, Semu Ernest ${ }^{1}$, Ikerra Susan ${ }^{4}$, Msanya Balthazar ${ }^{1} \&$ Masso Cargele ${ }^{3}$ \\ ${ }^{1}$ Department of Soil Science, Sokoine University of Agriculture, Morogoro, Tanzania \\ ${ }^{2}$ Department of Natural Resource Management, Selian Agricultural Research Institute, Arusha, Tanzania \\ ${ }^{3}$ International Institute of Tropical Agriculture, Nairobi, Kenya \\ ${ }^{4}$ Tanzania Fertilizer Regulatory Authority, Dar Es Salaam, Tanzania \\ Correspondence: Thuita Moses, International Institute of Tropical Agriculture, Nairobi, Kenya. E-mail: \\ m.thuita@cgiar.org
}

Received: January 23, 2018

Accepted: November 20, $2018 \quad$ Online Published: January 15, 2019

doi:10.5539/jas.v11n2p71

URL: https://doi.org/10.5539/jas.v11n2p71

\begin{abstract}
Low soil fertility has been a major factor to low maize yields in smallholder farms in sub-Saharan Africa. Technologies have been proposed including inorganic, fertilizers and plant growth promoting microorganisms. A study was conducted under greenhouse and field conditions to evaluate the effects of liquid inorganic fertilizer and microbiological products on growth, nutrient uptake and yield of maize. Products evaluated were Teprosyn (nitrogen, zinc phosphorus), BioSoil Crop Booster (BSCB) (Pseudomonas fluorescens), and Bio Soil Nitro plus $\left(\mathrm{BSN}^{+}\right)$(Acetobacter sp.). Treatments were: products alone (low and high rate), product + half rate phosphorus $\left(10 \mathrm{~kg} \mathrm{P} \mathrm{ha}^{-1}\right)$, half rate $\mathrm{P}$, full rate $\mathrm{P}\left(20 \mathrm{~kg} \mathrm{P} \mathrm{ha}^{-1}\right)$ and Control. All products were analysed for quality. None of the products met the label claims in nutrient/organism concentration. An increase of biomass was observed in the greenhouse for half rate $\mathrm{P}+\mathrm{BSCB}$ low rate and high rates for $\mathrm{BSCB}$ and $\mathrm{BSN}^{+}$compared to Control. Half rate $\mathrm{P}+$ $\mathrm{BSN}^{+}$low rate gave the highest grain yield which was similar full rate nitrogen and $\mathrm{P}$. $\mathrm{BSCB}$ and $\mathrm{BSN}^{+}$at low rates with $\mathrm{P}$ half rate resulted in an increase in biomass yield in the greenhouse. Efficacy of low rate $\mathrm{BSN}^{+}+$half rate $\mathrm{P}$ was demonstrated when applied at the recommended rates and combined with half rates of $\mathrm{N}$ and $\mathrm{P}$. A package of inorganic and Bio-fertilizers should be developed based on soil fertility status, and the quality of the inputs verified to ensure that they are conform to the label guarantee analysis.
\end{abstract}

Keywords: phosphate solubilization, nitrogen fixation, liquid fertilizer, quality control, efficacy testing

\section{Introduction}

The most important constraint to high crop yields in developing countries, and especially among resource-poor farmers, is low soil fertility status (Mohamadi \& Sohrabi, 2012). To sustainably produce enough food on dwindling land sizes requires a combination of approaches for example revised fertilizer formulation, better plant nutrition management, combination of organic and inorganic resources and improvement of agronomic practices at farm scale level. These must be geared towards sustainability both socially and environmentally to keep agriculture as a viable enterprise. Enhanced and sustainable soil fertility can be attained, among other things, through cultivation of crops capable of biological nitrogen fixation (BNF) and use of chemical and microbiological products (Gothwal et al., 2007; Woomer, 2012).

Microbiological products are composed of living microorganisms such as nitrogen (N) fixers, potassium (K) solubilizers and phosphorus (P) solubilizers, and molds or fungi which, when applied to seed or soil, colonize the rhizosphere and promote growth by converting nutritionally important elements (e.g. $\mathrm{N}$ and $\mathrm{P}$ ) from unavailable to available forms through biological processes such as nitrogen fixation or solubilization of insoluble phosphates (Rokhzadi et al., 2008). Microbiological products are cost-effective inputs for farmers (Hameeda et al., 2006), and have been used to increase crop yields in several countries. For example, in Cuba, several microbiological products composed of strains of Azotobacter, Rhizobium, Azopirillum or Burkhoderia are commercially produced and used in the cultivation of different crops. These microbiological products have proved to increase root and shoot elongation as well as yields of rice, beans, wheat, maize and sorghum (Ahmed, 2010). Phosphate solubilizing micro-organisms (PSM) (Khan et al., 2007) have been found to associate with the 
roots of plants, thus playing an important role in increasing P-availability to plants and thereby increasing the growth and crop yields (Kamlesh et al., 2010). Phosphate solubilizing microorganisms include bacteria of the genera Pseudomonas, Bacillus and Enterobacter, along with fungi like Penicillium and Aspergillus (Tilak et al., 2005).

Similarly, $\mathrm{N}_{2}$-fixing bacteria, mainly members of the genera Azotobacter and Azospirillum, have been isolated from the rhizospheres of various cereals and tested as bio-fertilizers to increase yields of the cereals and legumes through fixing atmospheric nitrogen (Bakulin et al., 2007; Gupta, 2004). Furthermore, Kaya et al. (2006) reported that treating seeds with commercial chemical products containing micro- and macro-nutrients has proved to improve germination and seedling establishment of wheat, soybean, sunflower and maize. However, based on studies conducted in Ethiopia, Kenya, and Nigeria, Jefwa et al. (2014) demonstrated that the efficacy of most of such products found in the marketplace were not generally granted because of poor quality and even 'snake oils'. Deficiencies in the regulatory framework in most countries of sub-Saharan Africa may explain the presence of sub-standard agricultural inputs in the marketplace (Masso et al., 2013). Selected microbial products and specialty fertilizers (e.g. liquid formulations) introduced in the Tanzanian and most of sub-Saharan Africa markets have not been sufficiently evaluated under local farming conditions of the country. With the recent improvement and enforcement of the regulatory framework by the relevant authorities in Tanzania, using such products calls for quality control to prevent fraud and protect the end-users against economic losses. This study was therefore carried out to evaluate the quality and efficacy of selected commercial products intended for the Tanzanian farmers.

\section{Materials and Methods}

\subsection{Materials}

The products used in the study are listed in Table 1 including label claims on mode of action, active ingredient and application rates. The application rates indicated were adopted in the study.

Table 1. A summary of label claims of the products tested

\begin{tabular}{|c|c|c|c|c|c|c|}
\hline Product & $\begin{array}{l}\text { Active } \\
\text { ingredient/s }\end{array}$ & Guarantee analysis & Application rate & Benefits to plants & Manufacturer & $\begin{array}{l}\text { Product } \\
\text { source }\end{array}$ \\
\hline Teprosyn & $\mathrm{NP}+\mathrm{Zn}$ & $\begin{array}{l}4.6 \%(\mathrm{~W} / \mathrm{V})=146 \mathrm{~g} \mathrm{~L}^{-1} \mathrm{~N} \\
(9 \% \mathrm{~W} / \mathrm{W})(9 \% \text { ureic } \\
\text { nitrogen }) \\
24 \%(\mathrm{~W} / \mathrm{V})=243 \mathrm{~g} \mathrm{~L}^{-1} \mathrm{P}_{2} \mathrm{O}_{5} \\
(15 \% \mathrm{~W} / \mathrm{W})\left(4.5 \% \mathrm{P}_{2} \mathrm{O}_{5}\right) \\
29 \%(\mathrm{~W} / \mathrm{W})=291 \mathrm{~g} \mathrm{~L}^{-1} \mathrm{Zn} \\
(18 \% \mathrm{~W} / \mathrm{W})\end{array}$ & $\begin{array}{l}\text { Maize: } 8 \text { or } 16 \mathrm{ml} \mathrm{kg}^{-1} \text { of } \\
\text { seed }\end{array}$ & $\begin{array}{l}\text { - Role in plant morphological } \\
\text { and physiological growth } \\
\text { through early seedling } \\
\text { establishment, strong root } \\
\text { systems and early development } \\
\text { of crop plants }\end{array}$ & $\begin{array}{l}\text { Yara UK Ltd, } \\
\text { Pocklington, York }\end{array}$ & $\begin{array}{l}\text { Tanzania } \\
\text { Fertilizer } \\
\text { Regulatory } \\
\text { Authority } \\
\text { (TFRA) }\end{array}$ \\
\hline $\begin{array}{l}\text { Bio-soil } \\
\text { Crop booster }\end{array}$ & $\begin{array}{l}\text { Pseudomonas } \\
\text { fluorescens }\end{array}$ & $\begin{array}{l}\text { CFU count shown on label is } \\
1 \times 10^{8} / \mathrm{ml} \text { (No method shown } \\
\text { how this CFU was counted) }\end{array}$ & $\begin{array}{l}\text { Seed treatment: } 5-10 \mathrm{ml} \\
\mathrm{kg}^{-1} \text { of seeds } \\
\text { Soil application: } 2.5 \mathrm{~L} \\
\mathrm{ha}^{-1} \text { mixed with organic } \\
\text { manure } \\
\text { Foliar spray: } 2.5 \mathrm{~L} \mathrm{ha}^{-1}\end{array}$ & $\begin{array}{l}\text { - Highly effective on root and } \\
\text { stem rot, damping off and } \\
\text { bacterial wilts. } \\
\text {-Effective against powdery and } \\
\text { downy mildew. }\end{array}$ & $\begin{array}{l}\text { Aadicon } \\
\text { Biotechnologies } \\
\text { Ltd, Mauritius }\end{array}$ & $\begin{array}{l}\text { From } \\
\text { Mauritius } \\
\text { through } \\
\text { TFRA }\end{array}$ \\
\hline $\begin{array}{l}\text { Bio-soil } \\
\text { Nitro+ }\end{array}$ & Acetobacter sp. & $\begin{array}{l}\text { CFU count shown on label is } \\
1 \times 10^{8} / \mathrm{ml} \text { (No method shown } \\
\text { how this CFU was counted) }\end{array}$ & $\begin{array}{l}\text { Seed treatment: } 5-10 \mathrm{ml} \\
\mathrm{kg}^{-1} \text { of seeds } \\
\mathrm{NB} \text { : Depending on field } \\
\text { conditions and type of } \\
\text { crop, dose can vary }\end{array}$ & $\begin{array}{l}\text { - Endophytic nitrogen fixing } \\
\text { living organism, it plays an } \\
\text { important role in germination of } \\
\text { plants } \\
\text { - Promotes growth by supplying } \\
80 \% \text { of nitrogen requirements }\end{array}$ & $\begin{array}{l}\text { Aadicon } \\
\text { Biotechnologies } \\
\text { Ltd, Mauritius }\end{array}$ & $\begin{array}{l}\text { From } \\
\text { Mauritius } \\
\text { through } \\
\text { TFRA }\end{array}$ \\
\hline
\end{tabular}

\subsubsection{Soil Analysis}

A clay soil (characterized as an Acrisol) was obtained for use in a greenhouse experiment which was conducted at the Department of Soil Science, Sokoine University of Agriculture (SUA), Tanzania located at latitude of $06^{\circ} 50^{\prime} \mathrm{S}$ and longitude $37^{\circ} 38^{\prime} \mathrm{E}$ at an altitude of $525 \mathrm{~m}$ above sea level. The bulk surface soil sample was ground to pass through a 2-mm sieve. The physico-chemical properties of the experimental soil were determined by standard procedures for $\mathrm{pH}$, total $\mathrm{N}$, extractable $\mathrm{P}$, organic carbon, calcium, magnesium potassium, Cation Exchange Capacity, Zn, Copper, Iron and Manganese (Bray \& Kurtz, 1945; Bremner \& Mulvaney, 1982; Chapman, 1965; McLean, 1986; Nelson \& Sommers, 1982; Lindsay \& Norvell, 1978). 


\subsubsection{Characterization of Teprosyn}

The total nutrient contents (i.e. $\mathrm{N}, \mathrm{P}$, and $\mathrm{Zn}$ based on the label guarantee analysis) in Teprosyn product (a liquid fertilizer) were determined using established laboratory procedures as follows for three batches. Total nitrogen in the Teprosyn product was determined by the micro-Kjedahl digestion-distillation method according to the procedure described by Bremner and Mulvaney (1982). Total P in the Teprosyn product was determined using the method as described by Murphy and Riley (1962). The total Zinc in Teprosyn was determined using the method as described by Lindsay and Norvell (1978).

\subsubsection{Microbiological Populations in Products}

Products from three different batches were evaluated for the total number of microorganisms in Bio Soil Crop Booster (BSCB) and Bio Soil Nitro plus $\left(\mathrm{BSN}^{+}\right)$was enumerated using the pour plate method in both undiluted and diluted aliquots of the product, using nutrient agar (NA). The average numbers of colonies were used to determine the number of microorganisms $(\mathrm{CFU} / \mathrm{ml})$ of $\mathrm{BSCB}$ or $\mathrm{BSN}^{+}$product. The number of colonies from the three replicate plates was determined and the number of total microorganisms of CFU was calculated using the following Equation 1:

$$
\text { Number of CFU/ml }=\text { Number of CFU counted } \times \text { Total dilution/Volume plated }(\mathrm{ml})
$$

\subsection{Methods}

\subsubsection{Greenhouse Experiments}

The pot experiments were conducted in the greenhouse of the Department of Soil Science, SUA in Morogoro region in February 2014 (before the onset of long rain season). Three $\mathrm{kg}$ of the bulk soil sample were placed into 4-L plastic pots, and arranged in a complete randomized design (CRD) with three replications. The treatments were: products (i.e. BSCB, BSN ${ }^{+}$and Teprosyn) alone at low rate $\left(10 \mathrm{ml} \mathrm{kg}^{-1}\right.$ of seed $)$ and high rate $\left(20 \mathrm{ml} \mathrm{kg}^{-1}\right.$ of seed), product $+10 \mathrm{~kg} \mathrm{Pha}^{-1}$ (half rate P), $10 \mathrm{~kg} \mathrm{P} \mathrm{ha}^{-1}, 20 \mathrm{~kg} \mathrm{Pha}^{-1}$ (full rate P) and absolute Control with no inputs. Potassium di-phosphate $\left(\mathrm{K}_{2} \mathrm{HPO}_{4}\right)$ was used as a source of $\mathrm{P}$. The volume of Teprosyn product recommended by the manufacturer for coating $1 \mathrm{~kg}$ maize seeds was $8 \mathrm{ml}$ (low rate) or $16 \mathrm{ml}$ (high rate) $\mathrm{kg}^{-1} \mathrm{of}$ seed and both were used. The seeds were placed in a small plastic bag and Teprosyn was added. The mixture was agitated gently for 1 minute. Subsequently, the treated seeds were placed on a sheet of filter paper and allowed to dry indoors for 30 minutes, before being planted in the pots. The BSCB (contained Pseudomonas fluorescens) inoculant was prepared in a plastic bucket by mixing $2.5 \mathrm{ml}$ of the concentrated BSCB with 2 liters of water and $2.5 \mathrm{~g}$ of sugar and left for 12 hours. This is equivalent to the manufacturer's instruction to mix 250 $\mathrm{ml}$ of product with $200 \mathrm{~L}$ water and $250 \mathrm{~g}$ sugar. Thereafter, $10 \mathrm{ml}$ of the mixture was used to inoculate one kilogram of maize seeds half an hour before planting. Similarly, the $\mathrm{BSN}^{+}$product (containing Acetobacter) was prepared by dissolving $2.5 \mathrm{ml}$ of $\mathrm{BSN}^{+}$product into $2 \mathrm{~L}$ of water. Thereafter, $10 \mathrm{ml}$ of the mixture was used to inoculate one kilogram of maize seeds half an hour before planting.

Three seeds of certified untreated SITUKA maize variety were planted on the potted soils and were thinned to two plants per pot 12 days after planting (DAP). Rates of $0.26 \mathrm{~g} \mathrm{~N}$ from urea $\left(\mathrm{CO}\left(\mathrm{NH}_{2}\right)_{2}\right)$ was applied to potted soils. To satisfy the suggested rates of $\mathrm{P}$ (i.e. 10 and $20 \mathrm{~kg} \mathrm{P} \mathrm{ha}^{-1}$ ) in treatments for evaluating the commercial products, $0.23 \mathrm{~g} \mathrm{P}\left(10 \mathrm{~kg} \mathrm{P} \mathrm{ha}^{-1}\right)$ and $0.449 \mathrm{~g} \mathrm{P}\left(20 \mathrm{~kg} \mathrm{P} \mathrm{ha}^{-1}\right)$ respectively, as $\mathrm{K}_{2} \mathrm{HPO}_{4}$ were applied. Nitrogen as Urea rate of $60 \mathrm{~kg} \mathrm{~N} \mathrm{ha}^{-1}$ was split applied $\left(30 \mathrm{~kg} \mathrm{~N} \mathrm{ha}^{-1}\right.$ for each application) at planting time and 21 days after planting (V3 growth stage). All treatments for Teprosyn and the other fertilizers were applied at planting time. The soils in the pots were watered to its field water holding capacity throughout the experimental period. At 35 DAP (V5-V6 growth stage), shoot dry matter was also determined after cutting the shoots of the two plants at 1 $\mathrm{cm}$ above the soil surface, drying in an oven at $65{ }^{\circ} \mathrm{C}$ to constant weight. The dried plant samples were cut into small pieces grounded and passed through a $0.5 \mathrm{~mm}$ sieve for analysis to determine the plant uptake of $\mathrm{P}$ and $\mathrm{Zn}$.

\subsubsection{Field Experiments}

A field experiment was conducted in on a clay soil (Acrisol) during the 2013/14 growing season to assess the effects of commercial products on growth and yields of SITUKA maize variety at SUA farm, where the soil used in the pot experiment was collected from SUA farm (before establishment of the field trial). The field was prepared by a tractor followed by harrowing. The products were evaluated using a randomized complete block design (RCBD) with three replications. The experimental unit size was $3 \times 3 \mathrm{~m}$ and the treatment structure was identical to the one used in the greenhouse. YaraMila cereal fertilizer $(23: 10: 5+3 \mathrm{~S}+2 \mathrm{MgO}+0.3 \mathrm{Zn})$ was used as a source of P. Nitrogen was applied at two splits of $30 \mathrm{~kg} \mathrm{~N} \mathrm{ha}^{-1}$ for a total of $60 \mathrm{Kg} \mathrm{N}^{-1}$ for all treatments except treatments with $\mathrm{BSN}^{+}$and BSCB (both low and high rates) alone or in combination with $\mathrm{P}$ which received at $30 \mathrm{~kg} \mathrm{~N} \mathrm{ha}^{-1}$ at planting, and the Control (no $\mathrm{N}$ applied). Biomass sampling was done at tasseling stage for the 
tissue analysis to determine $\mathrm{Zn}, \mathrm{P}$ and $\mathrm{N}$ uptake. Harvesting was done at physiological maturity for determination of grain yield.
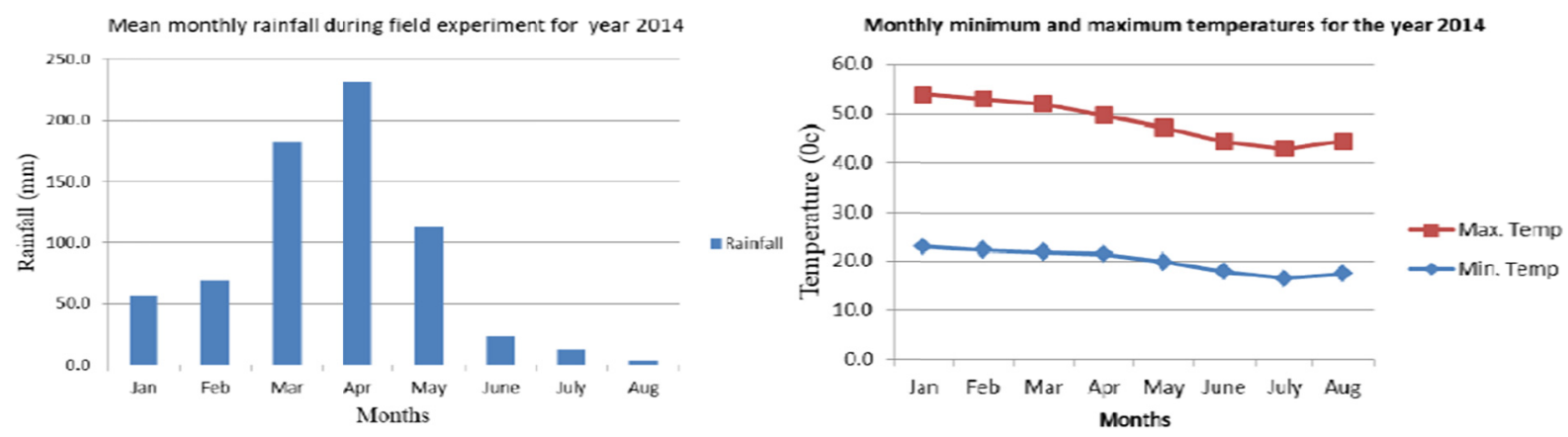

Monthly sunshine hours for the year 2014
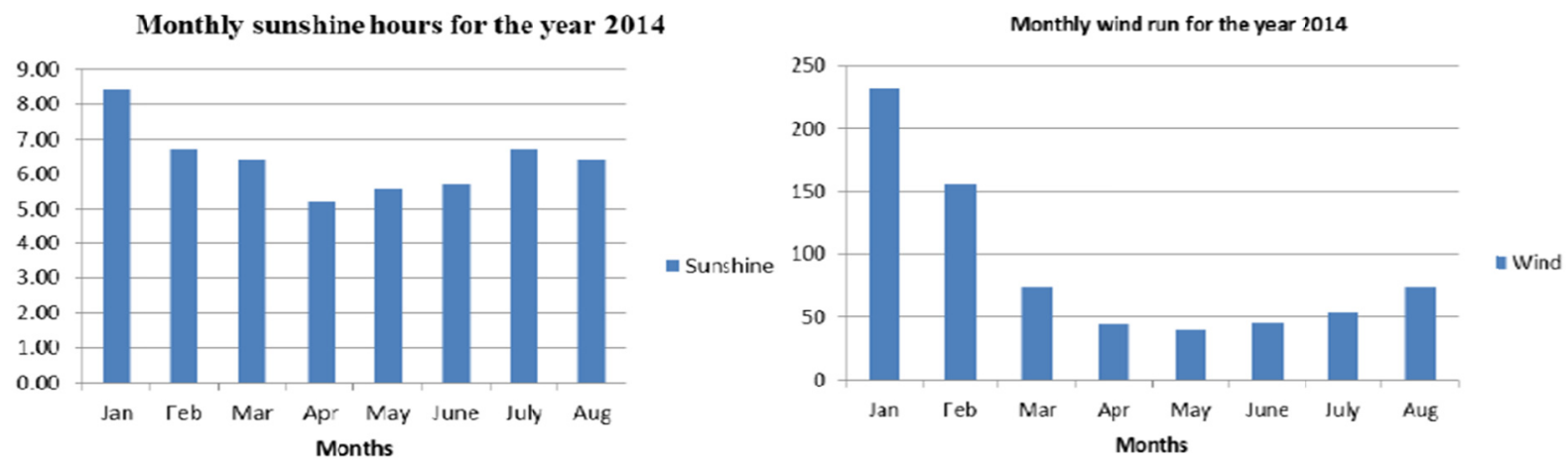

\begin{tabular}{|lllllllll|}
\hline Month & Jan & Feb & Mar & Apr & May & June & July & Aug \\
\hline Rainfall & 56.0 & 69.4 & 182.7 & 231.0 & 113.0 & 24.0 & 13.0 & 4.0 \\
Min. Temp & 22.9 & 22.2 & 21.8 & 21.3 & 19.8 & 17.8 & 16.4 & 17.4 \\
Max. Temp & 31.0 & 30.8 & 30.1 & 28.3 & 27.4 & 26.6 & 26.5 & 27.1 \\
Sunshine & 8.40 & 6.7 & 6.4 & 5.20 & 5.60 & 5.7 & 6.7 & 6.4 \\
Wind & 231.8 & 156.2 & 73.5 & 44.1 & 39.7 & 44.9 & 53.6 & 73.8 \\
\hline
\end{tabular}

Figure 1. Weather data recorded during field experiment at SUA farm

\subsection{Statistical Analysis}

The collected data were analyzed for variance using the SAS 9.3 computer software. Treatment means were compared using the Tukey Test at $\mathrm{p}<0.05$.

\section{Results}

\subsection{Soil and Commercial Products Analysis}

The physical-chemical properties of the experimental soil are presented in Table 2. The soil was classified as clay, while the chemical properties were rated according to Landon (1991), Okalebo, Gathua, and Woomer (2002), and Motsara and Roy (2008). Based on the classification, the levels of target nutrients (N, P and Zn) were low; hence, the soil was suitable for the trial. Total nutrient contents (macro and micronutrients) in Teprosyn, as determined in the present study are found in Table 3. There was $9.32 \% \mathrm{~N}$ which was similar to the expected amount of $9 \%$ as specified on the label, however levels of P (\%) and $\mathrm{Zn}(\%)$ were much lower than expected (2.72\% and $5.54 \%$ respectively) compared to $15 \%$ and $18 \%$ as indicated on the product label. Hence, when applied at the rates recommended on the product label, the user may not obtain the expected results as the amounts of $\mathrm{P}$ and $\mathrm{Zn}$ used will be less. Hence, quality control of agricultural inputs in the marketplace is crucial for farmers to obtain the value of their money and expected crop yields. The microbiological populations (CFUs) in $\mathrm{BSCB}_{\text {and }} \mathrm{BSN}^{+}$and in the experimental soil are shown in Table 3. The Laboratory values of CFU determined for each microbiological product were lower than the CFU specified by the manufacturer as quoted in the respective label. This in turn lowers the numbers of effective microorganisms delivered to the seed on inoculation lowering the chance of successful inoculation. However, it's noteworthy that the products contained the indicated organisms without contamination with undeclared micro-organisms. Both the liquid fertilizer and 
the microbiological products were sub-standard, demonstrating the need for better marketplace monitoring to enforce the quality standards for agricultural inputs and prevent fraud to protect the consumers as well as the credibility of the industry and the regulatory authority. Such issues could explain the low adoption of bio-fertilizers as result of insufficient promotion due the various uncertainties related to their field performance.

Table 2. The Physco-chemical characterization of the soil used

\begin{tabular}{llll}
\hline Property, unit & Unit & Value & Fertility level \\
\hline Sand & $\%$ & 41.0 & \\
Silt & $\%$ & 3.0 & \\
Clay & $\%$ & 56.0 & \\
pH $\left(\mathrm{H}_{2} \mathrm{O}\right)$ & - & 6.33 & Medium \\
Organic carbon & $\%$ & 1.72 & low \\
Total nitrogen & $\%$ & 0.14 & Low \\
Bray 1 P & $\mathrm{Mg} \mathrm{kg}^{-1}$ & 1.02 & Low \\
Exchangeable $\mathrm{Ca}$ & $\mathrm{Cmol}_{\mathrm{c}} \mathrm{kg}^{-1}$ & 6.35 & Medium \\
Exchangeable $\mathrm{Mg}$ & $\mathrm{Cmol}_{\mathrm{c}} \mathrm{kg}^{-1}$ & 3.22 & High \\
Exchangeable $\mathrm{Na}$ & $\mathrm{Cmol}_{\mathrm{c}} \mathrm{kg}^{-1}$ & 0.26 & Low \\
Exchangeable K & $\mathrm{Cmol}_{\mathrm{c}} \mathrm{kg}^{-1}$ & 1.10 & Medium \\
CEC & $\mathrm{Cmol}_{\mathrm{c}} \mathrm{kg}^{-1}$ & 23.0 & Medium \\
DTPA extractable Fe & $\mathrm{Cmol}_{\mathrm{c}} \mathrm{kg}^{-1}$ & 38.0 & Very high \\
DTPA extractable $\mathrm{Mn}$ & $\mathrm{Cmol}_{\mathrm{c}} \mathrm{kg}^{-1}$ & 67.5 & Very high \\
DTPA extractable $\mathrm{Zn}$ & $\mathrm{Cmol}_{\mathrm{c}} \mathrm{kg}^{-1}$ & 0.34 & Very low \\
DTPA extractable $\mathrm{Cu}$ & $\mathrm{Cmol}_{\mathrm{c}} \mathrm{kg}^{-1}$ & 2.43 & High \\
\hline
\end{tabular}

Table 3. Characterization of products used in the trials

\begin{tabular}{llll}
\hline Product & Parameter/active ingredient & Laboratory results & Manufacturer results \\
\hline $\mathrm{BSCB}$ & P. fluorescens $\left(\mathrm{CFU} \mathrm{ml}{ }^{-1}\right)$ & $1.9 \times 10^{4}$ & $1.0 \times 10^{8}$ \\
$\mathrm{BSN}^{+}$ & Acetobacter $\mathrm{sp} .\left(\mathrm{CFU} \mathrm{ml} \mathbf{l}^{-1}\right)$ & $1.1 \times 10^{2}$ & $1.0 \times 10^{8}$ \\
\hdashline Teprosyn & $\mathrm{N}(\%)$ & $9.32 \pm 0.15$ & 9 \\
& $\mathrm{P}(\%)$ & $2.72 \pm 0.08$ & 15 \\
& $\mathrm{Zn}(\%)$ & $5.54 \pm 0.11$ & 18 \\
\hline
\end{tabular}

\subsection{Greenhouse Trial}

\subsubsection{Nutrient Uptake}

There were significant differences in the P uptake $(\mathrm{p}<0.001)$ (Table 4$)$. The highest $\mathrm{P}$ uptake was obtained in the $\mathrm{P}$ (half rate) $+\mathrm{BSCB}$ (lower rate) $\left(1.653 \mathrm{~g}\right.$ plant $\left.^{-1}\right)$ and $\mathrm{P}$ (half rate) $+\mathrm{BSN}^{+}$low rate $\left(1.075 \mathrm{~g}_{\text {plant }}{ }^{-1}\right)$ treatments compared to the untreated Control treatment $0.392 \mathrm{~g} \mathrm{plant}^{-1}$ and the $\mathrm{P}$ alone treatments at the full rate $\mathrm{P}$ and the half rate which gave $0.217 \mathrm{~g} \mathrm{plant}^{-1}$ and $0.399 \mathrm{~g} \mathrm{plant}^{-1}$ respectively (Table 4). The lowest $\mathrm{P}$ uptake was obtained from the three products when applied alone (no external P) when applied at recommended lower rate but when the rates of the products applied at the high rates, the $\mathrm{P}$ and $\mathrm{Zn}$ uptake more than doubled for both $\mathrm{BSN}^{+}$and $\mathrm{BSCB}$ but no significant increases were observed for Teprosyn (Table 4).

Zinc showed significant differences in uptake between treatments with $\mathrm{P}$ (half rate) + BSCB (lower rate) having the highest amounts (1.192 $\left.\mathrm{mg}_{\text {plant }}{ }^{-1}\right)$ compared to the untreated Control $\left(0.4 \mathrm{mg} \mathrm{plant}^{-1}\right)$ and Teprosyn (high rate) which had $0.252 \mathrm{mg} \mathrm{plant}^{-1}$ (Table 4). The three products alone at the lower rates gave significantly low $\mathrm{Zn}$ uptake compared to the untreated Control $\left(0.146,0.171\right.$ and $\left.0.217 \mathrm{mg} \mathrm{plant}^{-1}\right)$ for Teprosyn, BSCB and BSN ${ }^{+}$respectively. 
Table 4. Maize shoot biomass yield and nutrient uptake from greenhouse trial

\begin{tabular}{|c|c|c|c|}
\hline Treatment & P uptake (mg plant $\left.{ }^{-1}\right)$ & Zn uptake (mg plant ${ }^{-1}$ ) & Shoot Biomass (g plant ${ }^{-1}$ ) \\
\hline Control & 0.390 & 0.400 & 0.650 \\
\hline $\mathrm{P}$ (half rate) & 0.40 & 0.270 & 0.480 \\
\hline $\mathrm{P}$ (full rate) & 0.22 & 0.120 & 0.260 \\
\hline Teprosyn (low rate) & 0.150 & 0.150 & 0.270 \\
\hline BSCB (low rate) & 0.190 & 0.170 & 0.280 \\
\hline $\mathrm{BSN}+($ low rate $)$ & 0.210 & 0.220 & 0.320 \\
\hline Teprosyn (high rate) & 0.210 & 0.250 & 0.350 \\
\hline BSCB (high rate) & 0.650 & 0.590 & 1.29 \\
\hline $\mathrm{BSN}+$ (high rate) & 0.750 & 0.890 & 1.480 \\
\hline $\mathrm{P}$ (half rate) + Teprosyn (low rate) & 0.580 & 0.290 & 0.54 \\
\hline $\mathrm{P}$ (low rate) + BSCB (low rate) & 1.650 & 1.190 & 1.710 \\
\hline $\mathrm{P}($ low rate $)+\mathrm{BSN}^{+}$(low rate) & 1.08 & 0.390 & 0.700 \\
\hline Mean & 0.540 & 0.410 & 0690 \\
\hline $\mathrm{CV}(\%)^{\dagger}$ & 41 & 32 & 33 \\
\hline $\mathrm{SED}^{*}$ & 0.18 & 0.10 & 0.18 \\
\hline
\end{tabular}

Note. $\dagger$ Coefficient of Variation in percentage; $\$$ Standard error of the difference.

\subsubsection{Biomass}

Statistical analysis of biomass gave significant differences $(\mathrm{p}<0.001)$ between treatments. The highest biomass being obtained from $\mathrm{P}$ (half rate) $+\mathrm{BSCB}$ (low rate) $\left(1.705 \mathrm{~g}\right.$ ) which similar $\mathrm{BSCB}$ and $\mathrm{BSN}^{+}$(both at the high rate) $(1.285$ and $1.483 \mathrm{~g})$ respectively. The products alone at the low rate recommended by the manufacturer generally gave the lowest amount of biomass.

\subsection{Field Trial}

\subsubsection{Nutrient Uptake}

There were significant differences in levels of $\mathrm{N}$ uptake due to treatments effects $(\mathrm{p}<0.05)$ (Table 5). Low $\mathrm{N}$ uptake was mainly observed when the products were applied alone (both low and high rates) all giving less than 2 $\mathrm{g}$ of $\mathrm{N} \mathrm{kg}^{-1}$ of biomass which was similar to the Control treatment. When the products were applied at the low rate with half rate $\mathrm{P}$, there was an increase in $\mathrm{N}$ uptake and all the products had at more than $2 \mathrm{~g} \mathrm{of} \mathrm{N} \mathrm{kg}^{-1}$ of biomass. However the amount of $\mathrm{N}$ uptake was similar to that obtained when $\mathrm{P}$ was applied without the three commercial products suggesting $\mathrm{P}$ was the main driver of $\mathrm{N}$ uptake.

Table 5. Maize grain yield and nutrient uptake from field trial

\begin{tabular}{|c|c|c|c|c|}
\hline Treatment & N Uptake $\left(\mathrm{g} \mathrm{kg}^{-1}\right)$ & P Uptake $\left(\mathrm{g} \mathrm{kg}^{-1}\right)$ & Zn Uptake (mg kg $\left.{ }^{-1}\right)$ & Grain Yield $\left(\mathrm{t} \mathrm{ha}^{-1}\right)$ \\
\hline Control & 1.859 & 0.204 & 0.9 & 2.210 \\
\hline $\mathrm{P}$ (half rate) & 2.026 & 0.209 & 0.9 & 2.490 \\
\hline$P$ (full rate) & 2.104 & 0.244 & 0.9 & 3.300 \\
\hline Teprosyn (low rate) & 1.943 & 0.207 & 0.9 & 2.440 \\
\hline BSCB (low rate) & 1.707 & 0.190 & 0.7 & 2.590 \\
\hline $\mathrm{BSN}+($ low rate $)$ & 1.553 & 0.173 & 0.9 & 1.990 \\
\hline Teprosyn (high rate) & 2.112 & 0.260 & 1.0 & 2.180 \\
\hline BSCB (high rate) & 1.707 & 0.233 & 0.7 & 1.380 \\
\hline $\mathrm{BSN}+$ (high rate) & 1.787 & 0.203 & 1.1 & 2.170 \\
\hline $\mathrm{P}$ (half rate) + Teprosyn (low rate) & 2.065 & 0.267 & 1.0 & 2.260 \\
\hline $\mathrm{P}$ (low rate) + BSCB (low rate) & 2.090 & 0.267 & 0.8 & 2.280 \\
\hline $\mathrm{P}($ low rate $)+\mathrm{BSN}^{+}$(low rate) & 2.150 & 0.243 & 0.9 & 3.690 \\
\hline Mean & 1.930 & 0.23 & 0.9 & 2.41 \\
\hline $\mathrm{CV}(\%)^{\dagger}$ & 8 & 10 & 19 & 9 \\
\hline $\mathrm{SED}^{\ddagger}$ & 0.12 & 0.01 & 0.02 & 0.19 \\
\hline
\end{tabular}

Note. $\dagger$ Coefficient of Variation in percentage; $\$$ Standard error of the difference. 
There were significant differences in $P$ uptake due to treatment $(p<0.05)$ (Table 5) with the lowest $P$ uptake being obtain when both Biofertlizers were applied at the lower rate with no $\mathrm{P}$ (less than $0.2 \mathrm{~g} \mathrm{~kg}^{-1}$ of biomass). However when combined with $\mathrm{P}$ application at the half rate, the $\mathrm{P}$ uptake rates increased to $0.243-0.267 \mathrm{~g} \mathrm{~kg}^{-1}$ of biomass suggesting a positive 2 way interaction of $\mathrm{P}$ application and the two Biofertlizers which was similar to $\mathrm{P}$ full rate. This indicated it may be possible to increase $\mathrm{P}$ uptake by use of the Biofertlizers with less $\mathrm{P}$ application. Zinc uptake did not give significant differences $(\mathrm{p}<0.05)$ due to the treatments applied with the lowest amount of $\mathrm{Zn}$ uptake being $0.7 \mathrm{mg} \mathrm{kg}^{-1}$ for BSCB alone at both rates and the highest $1.1 \mathrm{mg} \mathrm{kg}^{-1} \mathrm{BSN}^{+}$(high rate) (Table 5). Hence, it is recommendable to revisit the application rate and mode of placement of Teprosyn (containing $\mathrm{Zn}$ ) based on further investigation.

\subsubsection{Grain Yield}

There were significant differences $(\mathrm{p}<0.05)$ in grain yields due to treatment effects (Table 5). The highest grain yield was obtained from $\mathrm{P}$ (half rate) $+\mathrm{BSN}^{+}$(low rate) $+30 \mathrm{~kg} \mathrm{~N} \mathrm{ha}^{-1}$ and $\mathrm{P}$ (full rate) $+60 \mathrm{~kg} \mathrm{~N}^{-1}$ with at least $3 \mathrm{tha}^{-1}$ grain yield. The lowest grain yields were obtained from Biofertilizers with no P application (BSCB (high rate) and $\mathrm{BSN}^{+}$(low rate), both yielded less than $2 \mathrm{tha}^{-1}$ grain). The yields of $\mathrm{P}$ (half rate) $+\mathrm{BSCB}$ (low rate) and $\mathrm{P}$ (half rate) + Teprosyn (low rate) were comparable $\left(2.277\right.$ and $\left.2.257 \mathrm{t} \mathrm{ha}^{-1}\right)$ respectively.

\section{Discussion}

\subsection{Quality of Agricultural Inputs Versus Efficacy and Adoption}

All the three products tested in this study were sub-standard based on the guarantee analyses on the product labels; hence, they didn't conform to the regulatory requirements. This meant that the rates of application as indicated on the product label did not deliver the desired quantities of the active ingredients per unit amount of seeds. This would have consequently affected the crop performance. There is a strong need to enforce the quality standards through regular marketplace monitoring and education of product proponents and retailers of inputs to ensure that the product quality is maintained across the whole commercialization chain and product stored in good conditions to ensure that the shelf life is not affected by poor storage. Collaborative work between the regulatory authorities and the product proponents would be useful to identify at which level the product quality is deteriorated (e.g. sub-standard products at the package time, adulteration once in the marketplace, or poor storage among others). Similar efforts have resulted in better control quality of products in the market and even higher usage of Biofertilizers (Catroux et al., 2001).

Even though the market potential for Biofertilizers is huge in sub-Saharan Africa, the level of adoption remains limited and this is likely due to inappropriate formulations and a poor level of quality control capacity in the region. Similar challenges have been sighted in other parts of the world where market potential for Biofertilizers is high than actual consumption (Herrmann \& Lesueur, 2013; Bhattacharyya \& Jha, 2012). In addition to market control education of farmers on use and storage of the inoculants is critical. Based on the result of this study combination of bio-fertilizers with reduced rate of inorganic fertilizer may have a comparative advantage. For example, use of $\mathrm{P}$ at $10 \mathrm{~kg} \mathrm{ha}^{-1}+30 \mathrm{~kg} \mathrm{~N} \mathrm{ha}^{-1}+\mathrm{BSN}^{+}$gave similar yields to $20 \mathrm{~kg} \mathrm{P}+60 \mathrm{~kg} \mathrm{~N}^{-1}$; integration of $\mathrm{BSN}^{+}$, when applied at a correct rate, may therefore have an economic benefit given the low cost of $\mathrm{BSN}^{+}$per unit area compared to inorganic $\mathrm{N}$ and $\mathrm{P}$ fertilizers. Both $\mathrm{BSN}^{+}$and BSCB products on their own did not show increase above the Control for any of the parameters tested which could be probably due to the application rate being below expected, the effectiveness of the strains or other limiting nutrients other that $\mathrm{N}$ for $\mathrm{BSN}^{+}$and $\mathrm{P}$ for BSCB.

\subsection{Efficacy of Agricultural Inputs Versus Initial Soil Fertility}

The tested soil showed low N, P, Zn level as shown by the soil characterization. For specialized microorganisms such as Rhizobia to optimally function, other limiting factors should be well-controlled to maximize the performance of the tested products in terms of nutrient uptake, crop biomass, and yield. Sources of $\mathrm{P}$ were added to selected treatments in this study to determine whether additional P could improve the performance of the tested products. Results from the greenhouse trial indicated an increase in biomass production with a combination of $\mathrm{P}$ and the P. flourescens and Acetobacter sp. products at the higher rate. The findings of Peltonen-Sainio, Kontturi, and Peltonen (2006) who evaluated the effect of P seed coating on oat and found that $P$ seed coating enhanced early growth of oats but without increasing yields. However, Karanam and Vadez (2010) reported an increase in shoot biomass of two- and four-week-old seedlings due to P seed coating of pearl millet compared with non-coated seeds and panicle yield increases of $45-65 \%$ above the untreated Control. Tissue $\mathrm{P}$ concentration in the greenhouse trial showed enhanced $\mathrm{P}$ uptake in the plants receiving $10 \mathrm{~kg} \mathrm{P} \mathrm{ha}{ }^{-1}+$ biofertilizer ( $\mathrm{BSN}^{+}$and $\mathrm{BSCB}$ ) but in the field trial the $\mathrm{P}$ uptake generally remained below the optimal tissue concentration range of $0.4-0.8 \%$ (Lockman, 1969; Vandamme, 2008) even in the positive control with an 
application of $20 \mathrm{~kg} \mathrm{Pha}^{-1}$; the $\mathrm{Zn}$ concentration was also below the optimal ranged reported by the two authors (20-50 mg Zn/kg biomass) This may have contributed to the overall low yields observed. To address soil fertility limiting factors, such as $\mathrm{N}, \mathrm{P}, \mathrm{Zn}$, and organic matter content in the case of the study soil, there is a need to ensure that adequate application rates are used; this would take improvement of fertilizer recommendations in the context of integrated soil fertility management to tailor the directions for use to the initial soil fertility, the crop specific nutrient requirements, and local conditions. For instance, the current recommendation of $20 \mathrm{~kg} \mathrm{P}$ $\mathrm{ha}^{-1}$ may not be sufficient and further investigation is required to determine the effective application rate of $\mathrm{P}$ for the study soil. Equally important, other soil fertility limiting factors such as the low N, P, Zn and organic matter content among others in the study soil should be properly addressed to improve maize response to the tested commercial products. This is particularly important in most sub-Saharan Africa countries where most smallholder farmers apply blanket recommendations of fertilizers and other commercial agricultural inputs intended to improve soil fertility without adequate soil fertility diagnosis. Even when the quality of seed applied fertilizers such as Teprosyn or bio-fertilizers (e.g. BSCB and $\left.\mathrm{BSN}^{+}\right)$is good, studies have shown that they should be used in a complete fertilization program (i.e. in conjunction with other nutrients taking into consideration the initial soil fertility level) for adequate plant growth and yields as most soils suffer from multiple soil deficiencies (Ortas et al., 2012; Okalebo, 2009). Such products could be just used as complements and not substitutes to conventional fertilizers and soil conditioners (Jefwa et al., 2014; Richardson, Barea, McNeill, \& Prigent-Combaret, 2009).

The highest amounts of $\mathrm{N}$ in the ear leaf were observed when $\mathrm{P}$ was combined with the three products suggesting that there was increased $\mathrm{N}$ uptake when $\mathrm{P}$ was added. Similar findings have been reported by Vendan and Sundaram (1997), reported increased N-uptake in rice due to inoculation of Azotobacter and/or Azospirillum, in the presence of inorganic P. Similarly, inoculation with BSCB in the presence of P led to an increase in P uptake which has been reported elsewhere in soybean, strawberry (Fragaria ananasa) and cotton (Iman \& Azouni, 2008; Ahmad et al., 2012). These findings demonstrated that even for $\mathrm{N}$ fixing microorganisms or P solubilizers, there is a need of starter $\mathrm{N}$ or $\mathrm{P}$ to improve the performance of the microorganisms. The critical challenge that may require further investigation is to determine the threshold values of $\mathrm{N}$ or $\mathrm{P}$ required in various agro-ecological zones and for different crops above which the efficacy of the microbiological inoculants would be compromised.

\subsection{Performance of the Commercial Products on the greenhouse Versus Field}

When the performance of the products in the greenhouse and field the results do not show a direct correlation for nutrient uptake, biomass, and grain yield. Both microbial products alone at the higher rate did result in increased uptake of $\mathrm{P}, \mathrm{Zn}$ and biomass in the greenhouse probably due to better watering than when subjected to field conditions where soil moisture may have not been optimal for them throughout the growing season. The soils used in the study were deficient of both $\mathrm{P}$ and $\mathrm{Zn}$ and when applied together sometimes there is a $\mathrm{Zn}-\mathrm{P}$ antagonism significantly reducing $\mathrm{Zn}$ uptake and this could explain the $\mathrm{Zn}$ uptake in the field trial not showing significant differences in uptake. The imbalance of $\mathrm{Zn}$ and $\mathrm{P}$ could have been created when the intended levels of both nutrients were below the expected proportions. This has been previously observed by Ryan et al. (2008) and Zhang et al. (2012) who reported that application of macronutrient fertilizers high in phosphorus can significantly decrease plant $\mathrm{Zn}$ availability, and thus uptake from the soil due to complex $\mathrm{Zn}$-P interactions that alter both soil and plant factors. In both greenhouse and field trials, addition of $\mathrm{P}$ and $\mathrm{Zn}$ did not show any correlation with biomass or grain yield and this is attributed to both the poor quality of the product.

\section{Conclusions}

The three products did not meet the label claims when subjected to laboratory verification. There is a need to enforce existing and newly established quality standards for agricultural inputs to prevent fraud so that farmers have access to effective and high-quality products for use to improve crop productivity. This study in fact demonstrated that use of sub-standards products has little benefit on plant growth and crop yield. However, slight adjustment of the application rate (i.e. double of the manufacturer's recommendations) in combination with Pand / or N-fertilizer resulted in significant increase in growth parameters and biomass yields indicating the need to verify the commercial product quality so as to modify the application rate accordingly and integrate them into complete fertilization programs to improve crop response. The study has hence demonstrated the need to develop packages for use alongside the Biofertilizers and seed coating products such as Teprosyn as use of the products alone did not show any improvement on the yield above the untreated Control. The overall response to the currently recommended P- fertilizer rate in this study site indicated the need to revise fertilizer recommendation rates in the region probably not only for $\mathrm{P}$, but also for other plant nutrients. This study was conducted in the greenhouse and the field using only one site and a few commercial products, there is a need for further 
investigation at multiple locations using a large gamma of similar agricultural inputs before the current findings are generalized.

\section{Acknowledgements}

The authors are thankful to International Institute of Tropical Agriculture (IITA) under COMPRO II project funded by Bill \& Melinda Gates Foundation (BMGF) for providing funding for the study. They are also thankful to Sokoine University of Agriculture (SUA) and Messrs. G.P. Malecela, Salum Marangi, Mohamed Hamis and Dr. Consolatha Mhaiki who deserve special thanks for providing the experimental field and assistance during the Laboratory analysis.

\section{References}

Ahmad, Z. A., Qureshi, M. A., Akhtar, N., Iqbal, A., Mujeeb, F., \& Shakir, M. A. (2012). Role of phosphate solubilising bacteria (PSB) in enhancing P availability and promoting cotton growth. The Journal of Animal and Plant Sciences, 22(1), 204-210.

Ahmed, M. (2010). Management of fusarium wilt of tomato by soil amendment with Trichoderma konongii and a white sterile fungus. Indian Journal of Research, 5, 35-38.

Bakulin, M. K., Grudtsynam, A. S., \& Pletneva, A. (2007). Biological fixation of nitrogen and growth of bacteria of the genus Azotobacter in liquid media in the presence of Perfluoro carbons. Applied Biochemistry and Microbiology, 4, 399-402. https://doi.org/10.1134/S0003683807040072

Bhattacharyya, P. N., \& Jha, D. K. (2012). Plant growth-promoting rhizobacteria (PGPR): emergence in agriculture. World J Microbiol Biotechnol, 28, 1327-1350. https://doi.org/10.1007/s11274-011-0979-9

Bray, R. H., \& Kurtz, L. T. (1945). Determination of total, organic, and available forms of phosphorus in soils. Soil Science, 59, 39-45. https://doi.org/10.1097/00010694-194501000-00006

Bremner, J. M., \& Mulvaney, C. S. (1982). Total nitrogen. In A. L. Page, R. H. Miller, \& D. R. Keeny (Eds.), Methods of Soil Analysis (pp. 119-123). American Society of Agronomy and Soil Science Society of America, Madison.

Catroux, G., Hartmann, A., \& Revellin, C. (2001). Trends in rhizobial inoculant production and use. Plant Soil, 230, 21-30. https://doi.org/10.1023/A:1004777115628

Chapman, H. D. (1965). Cation exchange capacity. In C. A. Black (Ed.), Methods of Soil Analysis (pp. 891-901, Part 2, Number 9 in the Series Agronomy). Am. Inst. Agronomy, Madison, Wisconsin.

Date, R. A. (2000). Inoculated legumes in cropping systems of the tropics. Field Crops Res., 65, $123-136$. https://doi.org/10.1016/S0378-4290(99)00082-9

Gothwal, R. K., Nigam, V. K., Mohan, M. K., Sasmal, D., \& Ghosh, P. (2007). Screening of nitrogen fixers from rhizospheric bacterial isolates associated with important desert plants. Applied Ecology and Environmental Research, 6(2), 101-109. https://doi.org/10.15666/aeer/0602_101109

Gupta, A. K. (2004). The complete technology book on biofertilizers and organic farming (p. 620). National Institute of Industrial Research Press, India.

Hameeda, B., Rupela, O., Reddy, G., \& Satyavani, K. (2006). Application of plant growth-promoting bacteria associated with composts and macrofauna for growth promotion of Pearl millet (Pennisetum glaucum L). Biology and Fertility of Soils, 43(2), 221-227. https://doi.org/10.1007/s00374-006-0098-1

Herrmann, L., \& Lesueur, D. (2013). Challenges of formulation and quality of biofertilizers for successful inoculation. Applied Microbiology and Biotechnology, 97, 8859-8873. https://doi.org/10.1007/s00253-0135228-8

Iman, M., \& Azouni, E. I. (2008). Effect of phosphate solubilizing fungi on growth and nutrient uptake of soybean plants. Journal of Applied Sciences Research, 4(6), 592-598.

Jefwa, J., Pypers, P., Jemo, M., \& Thuita, M. (2014). Do Commercial Biological and Chemical Products Increase Crop Yields and Economic Returns under Smallholder Farmer Conditions? (pp. 81-96). Springer, Netherlands. https://doi.org/10.1007/978-3-319-07662-1_7

Kamlesh, K. M., Sukumar, M., Manish, K., Mahesh, S. Y., Geeta, S., \& Anil, K. S. (2010). Co-inoculation of the endophytic fungus Piriformospora indica with the phosphate-solubilising Bacterium Pseudomonas striata affects population dynamics and plant growth in chickpea. Biology and Fertility of Soils, 46, 169-174. https://doi.org/10.1007/s00374-009-0421-8 
Karanam, P. V., \& Vadez, V. (2010). Phosphorus coating on pearl millet seed in low P Alfisol improves plant establishment and increases stover mover than seed yield. Experimental Agriculture, 46(4), 457-469. https://doi.org/10.1017/S0014479710000608

Kaya, M. D., Okçu, G., Atak, M., Çikili, Y., \& Kolsarici, O. (2006). Seed treatment to overcome salt and drought stress during germination in sunflower (Helinathus annus L.). European Journal of Agronomy, 24, $291-295$. https://doi.org/10.1016/j.eja.2005.08.001

Khan, M. S., Zaidi, A., \& Wani, P. A. (2007). Role of phosphate-solubilizing microorganisms in sustainable agriculture: A review. Agronomy for Sustainable Development, 27, 29-43. https://oi.org/10.1051/ agro:2006011

Landon, J. L. (1991). Booker Tropical Soil Manual. A handbook for soil survey and agricultural land evaluation in the tropics and subtropics (pp. 113-138). Longman Group FE limited, New York.

Lindsay, W. L., \& Norvell, W. A. (1978). Development of a DTPA soil test for zinc, iron, manganese and copper. Soil Sci. Soc. Am. J., 42, 421-428. https://doi.org/10.2136/sssaj1978.03615995004200030009x

Lockman, R. B. (1969). Relationships between corn yields and nutrient concentration in seedling whole-plant samples (p. 97). American Society of Agronomy, Madison, Wisconsin.

Masso, C., Jefwa, J., Jemo, M., Thuita, M., Tarus, D., \& Vanlauwe, B. (2013). Impact of inadequate regulatory frameworks on the adoption of bio-fertilizers (e.g. PGPR) technologies: A case study of sub-Saharan Africa. In M. S. Reddy, R. I. Ilao, P. S. Faylon, W. D. Dar, R. Sayyed, H. K. Sudini, ... A. Armanda (Eds.), Recent advances in biofertilizers and biofungicides (PGPR) for sustainable agriculture. Proceedings of 3rd Asian Conference on Plant Growth-Promoting Rhizobacteria (PGPR) and other Microbials, Manila, Philippines, 21-24 April, 2013 (pp. 276-286). CAB Direct.

McLean, E. O. (1982). Soil pH and lime requirement. In A. L. Page, R. H. Miller, \& D. R. Keeney (Eds.), Methods of soil analysis. Part 2: Chemical and microbiological properties (Agronomy 9, pp. 199-223). Amer. Soc. Agron. Madison, WI.

Mohamadi, K., \& Sohrabi, Y. (2012). Bacterial Biofertilizers for sustainable crop production: A review. ARPN Journal of Agricultural and Biological Science, 7(5), 307-316.

Motsaram, M. R., \& Roy, R. N. (2008). Guide to laboratory establishment for plant nutrient analysis. FAO Fertilizer and Plant Nutrition Bulletin No. 19 (pp. 101-122). Food and Agriculture Organization of the United Nations, Rome.

Murphy, J., \& Riley, J. P. (1962). A modified single solution method for the determination of phosphate in natural waters. Anal. Chem. Act., 27, 31-36. https://doi.org/10.1016/S0003-2670(00)88444-5

Nelson, D. W., \& Sommer, L. E. (1982). Total carbon, organic carbon, and organic matter. In A. L. Page (Ed.), Methods of Soil Analysis (2nd ed., ASA Monograph 9, pp. 539-579). Amer. Soc. Agron. Madison, WI.

Okalebo, J. R. (2009). Recognizing the constraint of soil fertility depletion and technologies to reverse it in Kenyan agriculture. Moi University Inaugural Lecture 6 Series, 1, 33-50.

Okalebo, J. R., Gathua, K. W., \& Woomer, P. L. (2002). Laboratory methods of plant and soil analysis: A working manual (2nd ed.).

Ortas, I. (2012). Do maize and pepper plants depend on mycorrhizae in terms of phosphorus and zinc uptake? Journal of Plant Nutrition, 35(11), 1639-1656. https://doi.org/10.1080/01904167.2012.698346

Peltonen-Sainio, P., Kontturi, M., \& Peltonen, J. (2006). Phosphorus seed coating enhancement on early growth and yield components in oat. Agronomy Journal, 98, 206-211. https://doi.org/10.2134/agronj2005.0141

Richardson, A., Barea, J.M., McNeill, A., \& Prigent-Combaret, C. (2009). Acquisition of phosphorus and nitrogen in the rhizosphere and plant growth promotion by microorganisms. Plant and Soil, 321, 305-339. https://doi.org/10.1007/s11104-009-9895-2

Rokhzadi, A., Asgharzadeh, A., Darvish, F., Nour-Mohammadi, G., \& Majidi, E. (2008). Influence of plant growth promoting Rhizobacteria on dry matter accumulation of Chickpea (Cicer arietinum L) under field conditions. American-Eurasian Journal of Agricultural and Environmental Sciences, 3(2), 253-257.

Ryan, M. H., McInerney, J. K., Record, I. R., \& Angus, J. F. (2008). Zinc bioavailability in wheat grain in relation to phosphorus fertiliser, crop sequence and mycorrhizal fungi. Journal of the Science of Food and Agriculture, 88(7), 1208-1216. https://doi.org/10.1002/jsfa.3200 
Sanchez, P. A. (2010). Tripling crop yields in tropical Africa. Nature Geosci, 3, 299-300. https://doi.org/10.1038/ ngeo853

Tilak, K. V. B. R., Ranganayaki, N., Pal, K. K., De, R., Saxena, A. K., Nautiyal, C. S., Mittal, S., ... Johri, B. N. (2005). Diversity of plant growth and soil health supporting bacteria. Current Science, 89(Suppl. 1), 136-15.

Vandamme, E. (2008). Nutrient deficiencies in soils of Walungu, South-Kivu, Democratic Republic of Congo. Katholieke Universiteit Leuven, Belgium.

Vendan, R. T., \& Sundaram, M. D. (1997). Effect of biological nitrogen fixation in relation to growth and yield of certain rice varieties. Journal of Ecobiology, 9(4), 281-7.

Woomer, P. L. (2012). Integrated Soil Fertility Management in Africa: From Microbes to Markets: Conference Information, Program and Abstracts (p. 122). An international conference held in Nairobi, Kenya, October 22-26, 2012, CIAT, Kenya.

Zhang, Y. Q., Deng, Y., Chen, R.Y., Cui, Z. L., Chen, X. P., Yost, R., ... Zou, C. Q. (2012). The reduction in zinc concentration of wheat grain upon increased phosphorus-fertilization and its mitigation by foliar zinc application. Plant and Soil, 361, 143-152. https://doi.org/10.1007/s11104-012-1238-z

\section{Copyrights}

Copyright for this article is retained by the author(s), with first publication rights granted to the journal.

This is an open-access article distributed under the terms and conditions of the Creative Commons Attribution license (http://creativecommons.org/licenses/by/4.0/). 